\title{
VEGFR Tyrosine Kinase Inhibitor
}

National Cancer Institute

\section{Source}

National Cancer Institute. VEGFR Tyrosine Kinase Inhibitor. NCI Thesaurus. Code C93259.

Any substance that inhibits vascular endothelial growth factor receptor, a family of tyrosine kinase receptors involved in the formation of blood vessels. 